\title{
Mechanisims of asthma and allergic disease - 1069. Down regulation of IL-13 secretion in mononuclear cells by a beta-adrenergic blocker
}

\author{
Fatemeh Hajighasemi \\ From 2nd WAO International Scientific Conference (WISC 2012) \\ Hyderabad, India. 6-9 December 2012
}

\section{Background}

Beta-adrenergic blockers such as propranolol have been commonly used for treatment of several cardiovascular complications such as arterial hypertension and arrhythmias. Anti-inflammatory effects of propranolol have also been reported. Interleukin-13 (IL-13) (a Th2-type cytokine) is a mediator of airway inflammation and increases in immediate-type allergy. In this study the effect of propranolol on IL-13 secretion in human peripheral blood mononuclear cells (hPBMCs) have been investigated in vitro.

\section{Methods}

HPBMCs were used in this study. The cells were cultured in complete RPMI medium and then incubated with different concentrations of propranolol $\left(4 \times 10^{-7}-4 \times 10^{-4} \mathrm{M}\right)$ for 24 hours. The level of IL-13 secreted in the cell culture supernatants was measured with the enzyme-linked immunosorbent assay (ELISA) kits (R\&D systems).

\section{Results}

Propranolol significantly and dose-dependently reduced IL-13 production in hPBMCs, compared to untreated control cells.

\section{Conclusions}

According to the results of this study, propranolol considerably decreased the IL-13 expression in hPBMCs. Propranolol with its inhibitory effect on IL-13 production may be useful in alleviating the IL-13- induced respiratory inflammation in related diseases such as chronic obstructive pulmonary disease (COPD) and asthma. Therefore propranolol along with its chronic long-term

Immunology, Department of Immunology, Faculty of Medicine, Shahed University, Tehran, Iran usage in cardiac problems, might have potential implication in inflammatory disorders.

Published: 23 April 2013

doi:10.1186/1939-4551-6-S1-P66

Cite this article as: Hajighasemi: Mechanisims of asthma and allergic disease - 1069. Down regulation of IL-13 secretion in mononuclear cells by a beta-adrenergic blocker. World Allergy Organization Journal 2013 6(Suppl 1):P66.
Submit your next manuscript to BioMed Central and take full advantage of:

- Convenient online submission

- Thorough peer review

- No space constraints or color figure charges

- Immediate publication on acceptance

- Inclusion in PubMed, CAS, Scopus and Google Scholar

- Research which is freely available for redistribution
C Biomed Central 